\title{
Climate Change and Primary Birch Forest (Betula pubescens ssp. czerepanovii) Succession in the Treeline Ecotone of the Swedish Scandes
}

\author{
Leif Kullman \\ Department of Ecology and Environmental Science \\ Umeå University, SE 90187 Umeå, Sweden \\ leif.kullman@umu.se
}

\begin{abstract}
In a context of recent climate change, the conversion of treeless alpine tundra to mountain birch (Betula pubescens ssp. czerepanovii) forest was studied by repeat photography, demographic and growth surveillance in permanent plots. In addition, flora change was recorded within the emerging birch forest stand. The study was initiated in 1980, when a large snow bank covered the site well into mid-July. Climate warming and associated enhanced snow melt since the early 20th century had made the snow disappear earlier during most summers. In response, a fairly dense population of seed-regenerated low-growing birch saplings gradually emerged. During subsequent decades, this population grew substantially in numbers. The population stagnated in average height until the early 1980s, when height growth and recruitment accelerated. Thereafter, a dense stand of tree-sized birches emerged. Concurrently, the character of the ground cover transformed from alpine to forest, as the presence of a tree layer governs the composition of the lower vegetation strata. Possibly, the course of elevational subalpine forest expansion in a hypothetical case of further climate warming is suggested by the present study. The establishment of this forest stand bears some resemblance to the first Holocene mountain birch forests.
\end{abstract}

Keywords: Tree line ecotone, Betula pubescens ssp. czerepanovii, climate change, snow cover phenology, repeat photography, age structure.

\section{INTRODUCTION}

Alpine tree line ecotones are renowned as complex and dynamic vegetation and landscape elements, ultimately conditioned by heat deficiency and locally modulated by topoclimatic parameters, biotic and human interactions (Tranquillini 1979; Körner 2007; Holtmeier 2009; Harsch et al. 2009; Smith et al. 2009; Kullman 2010; Elliott 2011; Ettinger \& HilleRisLambers 2013; Kim \& Lee 2015). Accordingly, tree lines world-wide have responded with various degrees of upshifts during the past 100 years, characterized by climate warming and ceasing human impacts, e.g. pastoralism and logging (Aas 1969; Kullman 1979; Esper \& Schweingruber 2004; Kapralov et al. 2006; Danby \& Hik 2007; Shiyatov 2007; Devi et al. 2008; Harsch et al. 2009; Elliott \& Kipfmueller 2011; Holtmeier \& Broll 2012; Sing et al. 2012).

The Scandes is one of the regions where these aspects have been most intensively studied, by direct monitoring of different species on a centennial scale (Aas 1969; Kullman 1979, 2015a; Hofgaard \& Dalen 2011; Kullman \& Öberg 2009). Although tree line displacements exceeding $200 \mathrm{~m}$ have been recorded along this entire mountain chain, the average elevation advance is smaller, due to local constraints of the kind outlined above.

Most existing studies rely on the tree line, i.e. the upper limit of solitary tree-sized (> $2 \mathrm{~m}$ tall) specimens. Intuitively, multi-site advanced tree lines should signal improved growth preconditions for trees on high altitudes in the mountains. In contrast to model predictions (Boer et al. 1990: Kellomäki et al. 1997; Moen et al. 2004), few empirical studies have conclusively evidenced substantial shifts in the position of the upper range of closed forest communities, i.e. the forest limit. However, some studies have demonstrated marginal afforestation by means of increased density of prior only sparsely treed landscapes at the forest-alpine tundra transition (Kullman 1991, 2007, 2010, 2012). Practically no direct evidence exists of emergence of closed forest communities (all vegetation strata) on prior treeless alpine tundra (Kullman in press a), implying a fundamental ecosystem shift to forest 
vegetation (but see Nordhagen 1956). This circumstance may be a consequence of disequilibrium mechanisms and/or sparsity of old records and problems to define the forest limit in a way that enables adequate comparisons in time and space (Hustich 1979; Kullman 2010, in press b).

Here, the primary succession, and its ecological correlates, of a discrete mountain birch forest (Betula pubescens ssp. czerepanovii) stand, are accounted for and analyzed in a context of climate change during the past 100 years or so. Descriptive data depicting dynamic landscape processes of this kind are urgently needed in order to enable the generation of realistic and projective landscape models for future environmental conditions. The present study complies with a historical-descriptive approach to landscape ecological science (cf. Oldfield 2005).

\section{STUdy AREA}

The study is located to the east-facing flank of Mt. Getryggen (peak $1382 \mathrm{~m}$ a.s.l.) in the southern Swedish Scandes, approx. 63 ${ }^{\circ} 10^{\prime} \mathrm{N}, 12^{\circ} 21^{\prime} \mathrm{E}, 750 \mathrm{~m}$ a.s.l. (Fig.1). The concerned site belongs to the tree line ecotone, i.e. the transition zone between closed mountain birch forest and the treeless alpine tundra above. The investigated site is $155 \mathrm{~m}$ below the local birch tree line.

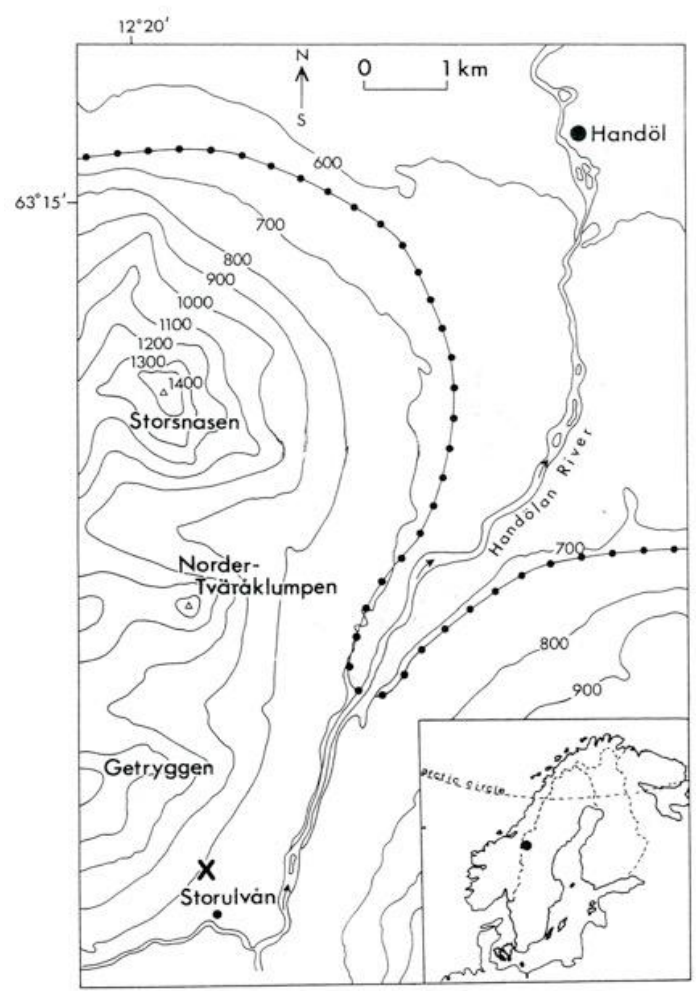

Fig1. Location map, showing the position of the study site on the south-east facing slope of Mt. Getryggen in the southern Swedish Scandes. The dotted line indicates the position of the pine (Pinus sylvestris) tree line.

The bedrock is composed of amphibolite and gneisses, covered with glacifluvial deposits, glacial till and peat. The nearest nearest official weather station (Storlien/Visjövalen, $642 \mathrm{~m}$ a.s.l. and $20 \mathrm{~km}$ to the northwest) provides records for the so-called normal period 1961-90. The mean temperatures for January, July, and the year were $-7.6{ }^{\circ} \mathrm{C}, 10.7{ }^{\circ} \mathrm{C}$, and $1.1^{\circ} \mathrm{C}$, respectively. Mean annual precipitation is $857 \mathrm{~mm}$ of which $45 \%$ falls as snow (data provided by the Swedish Meteorological and Hydrological Institute).

The study slope is characterized by an undulating geomorphic macro structure, manifesting as elongated crests and intervening troughs and terraces. This pattern, in combination with current wind streams, influences the snow accumulation modes, causing windswept crests with sparse and early melting snow cover, sharply contrasting with deep snow packs in the deeper and more sheltered terrain below. Old-age ribbon birch forest, without recent regeneration, prevail in the upper parts of the modestly sheltered and snow-poor slopes. The bottom swales have for long been devoid of closed birch forest due to late snow melt and a short growing season. 
Climate Change and Primary Birch Forest (Betula pubescens ssp. czerepanovii) Succession in the Treeline Ecotone of the Swedish Scandes

The local treeline of mountain birch, defined as the maximum elevation of at least $2 \mathrm{~m}$ tall specimens, is currently at $905 \mathrm{~m}$ a.s.l. During the period 1915 to 2007 , the tree line advanced by about $100 \mathrm{~m}$ to its present-day elevation (Kullman \& Öberg 2009).

The dynamism of the ground vegetation structure and physiognomy is influenced by summer grazing and trampling by semi-domestic reindeer. Close to the valley floor, a Sami dwelling site prevailed until the early 20th century, causing some thinning of the lower birch forest, which obviously did not affect the treeline ecotone. In parallel with substantial and consistent growth of reindeer herds in the region since the early 20th century (Fig. 2), the birch treeline advanced substantially. Impact on tree line positions of reindeer grazing has been suggested more important than temperature (Olofsson et al. 2009; van Bogaert et al. 2011), although questioned as a general phenomenon by Kullman (2015a).

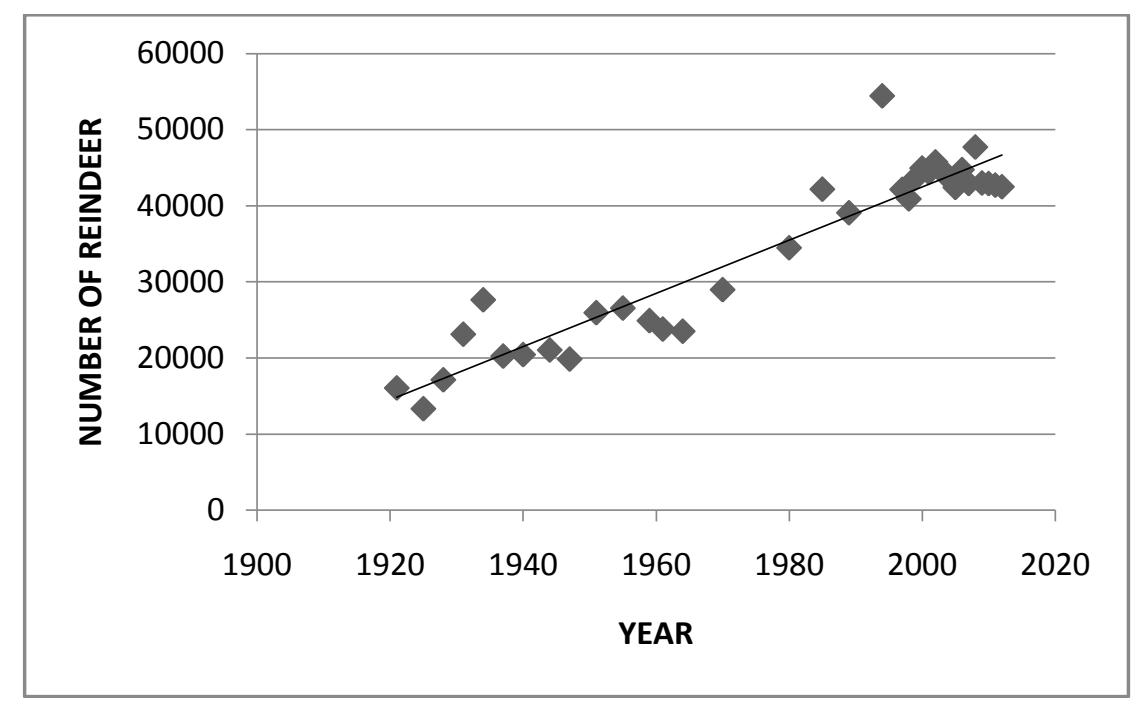

Fig2. Trend of numbers of reindeer numbers in the study region (counties of Jämtland and Dalarna), according to official statistics (SOU 2006).

Regional air temperature evolution since 1901 is represented by Fig. 3. During the period 1901 to 2015 the mean temperature for the months June to August rose by $1.6^{\circ} \mathrm{C}$, although with great annual and periodic variability. Winter temperature (December to February) increased by virtually the same amount as the summer temperature. Since the major part of the study plot is covered by a deep snow drift during most of the winter (Fig. 4, 5), variations in winter temperature are reasonably of relatively small importance for the birch vegetation evolution, although the timing of snow melt needs to be considered in that connection.

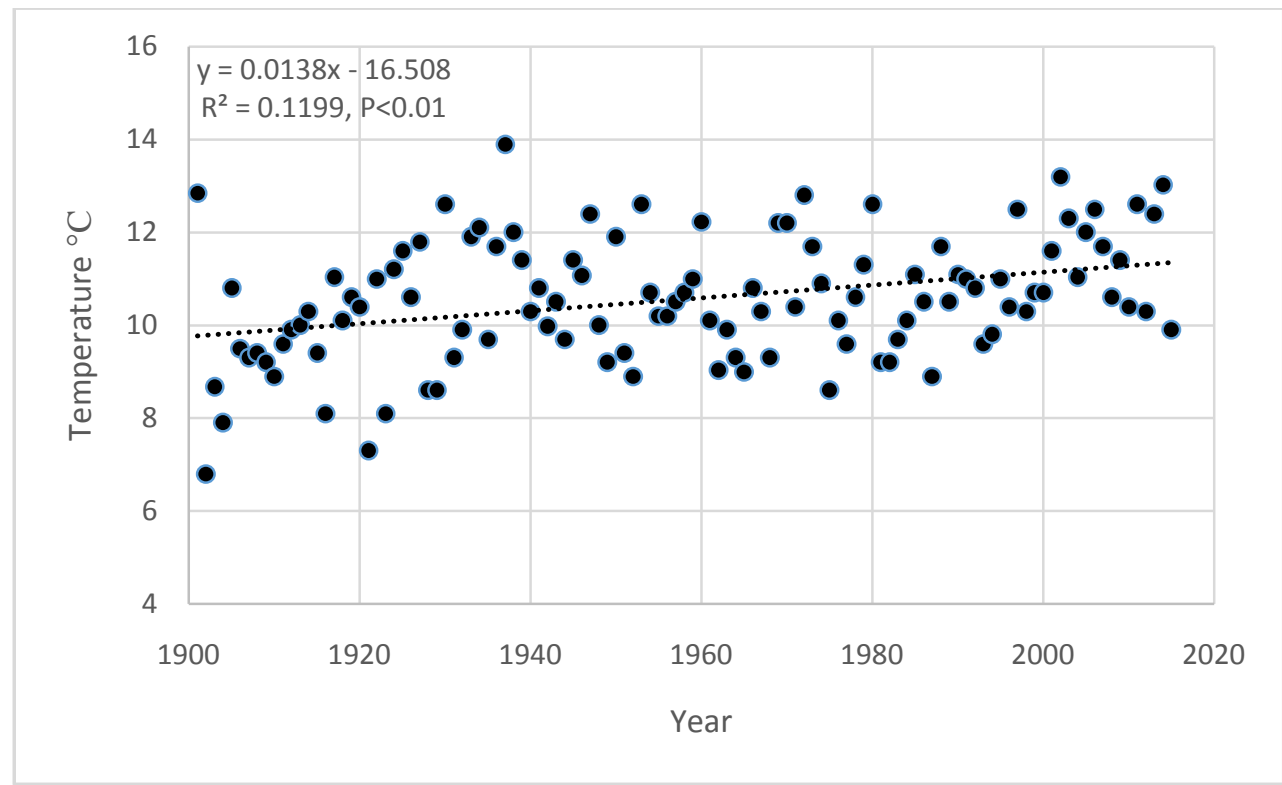

Fig3. Annual mean air temperature records and long-term trend (June-August) for the meteorological station Storlien/Visjövalen. 
Relevant aspects of Holocene landscape and tree line history are provided by Lundqvist $(1969,2012)$, Kullman (1995, 2005, 2013, 2015), Bergman et al. (2005); Öberg \& Kullman (2011).

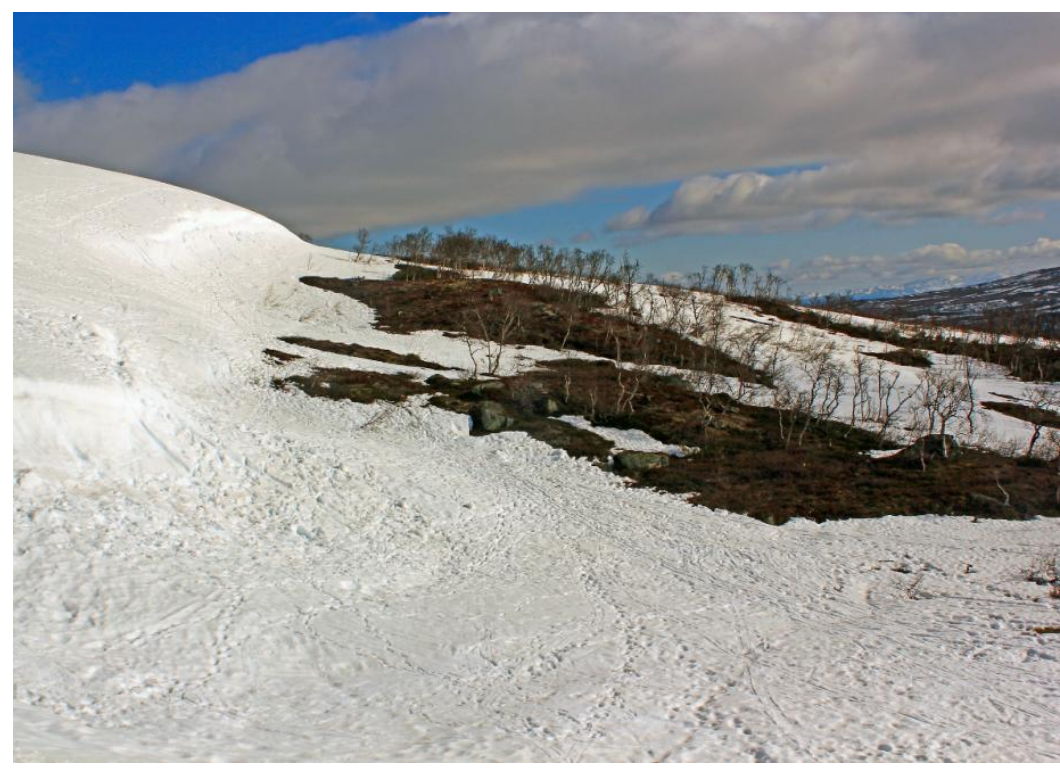

Fig4. Characteristic winter/spring view of the study site. The emerging birch population (to the left) is entirely snow-covered for most of the winter and well into the spring and early summer, while the older birch forest (to the right) occupies a part of the landscape with less and earlier disappearing snow. Photo: 2011-04-30.

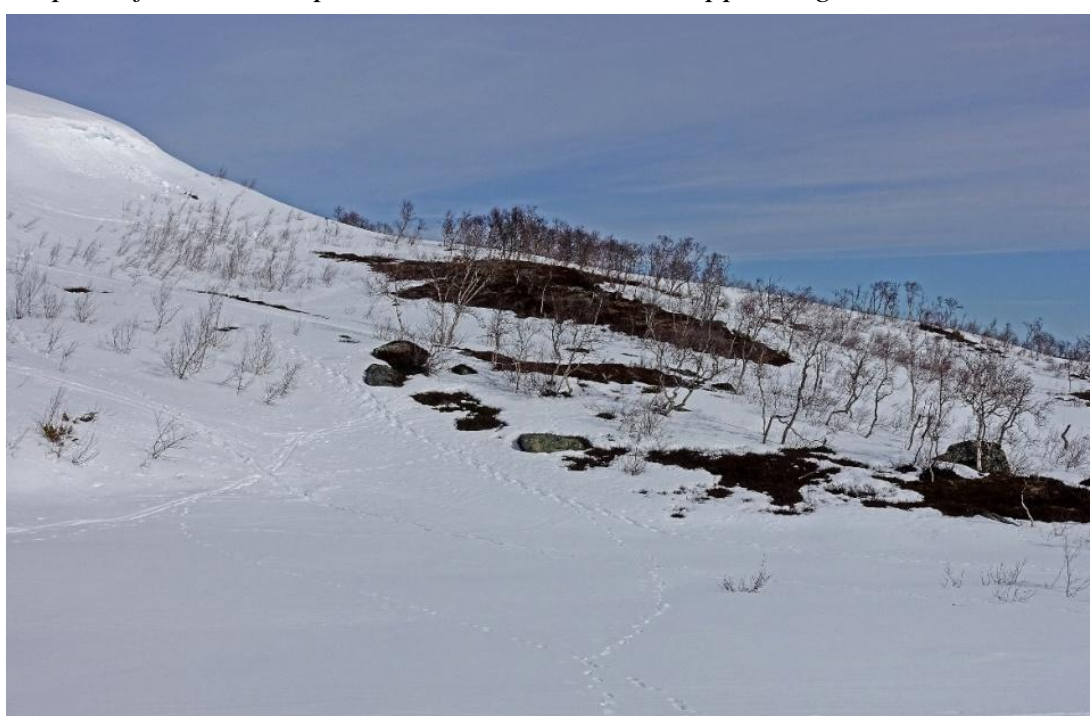

Fig5. The same view as in Fig. 4, five years later. Progressive height growth and a less snow-rich winter (2015/2016) have made the birch population more visible. Photo: 2016-05-02.

\section{MATERIAl AND MeTHODS}

This study relies principally on repeat landscape photography and age structure and demographic analysis of an extant birch stand, currently constituting the tree line ecotone. The first-mentioned approach is known to provide objective, holistic, qualitative and semi-quantitative aspects of landscape change in open habitats (Rapp 1996; Klasner \& Fagre 2002; Zier \& Baker 2006; Webb et al. 2010; Kullman 2014b). Carefully executed and interpreted, age structure analysis of trees, may provide insight into the temporal evolution of stand structure and dynamics of biogeographic zonality, by integrating natality and mortality of individual specimens (Johnson et al. 1994; Villalba \&Veblen 1997; Kullman 2014a, b, 2015c).

In the present case, within a large plots $(50 \times 100 \mathrm{~m})$, five circular permanent plots with a $2 \mathrm{~m}$ radius, intended for demographic and growth surveillance, were randomly dispersed in the bottom of the topographic trough and at its lower slopes. These plots were established in 1980 and embraced an emerging and dense population of low-growing birches, judged to be fairly new recruits. During the following decades, the plots have been surveyed intermittently during all seasons, with respect to number of stems, height and vigor of birches. At these occasions, the entire population, containing the 
Climate Change and Primary Birch Forest (Betula pubescens ssp. czerepanovii) Succession in the Treeline Ecotone of the Swedish Scandes

plots, was photographed from various positions, as a measure to depict the overall landscape evolution in consequence of the obtained demographic changes within the permanent plots. The latest survey was carried out in July 2015.

In 2013, the static age structure of the population was assessed on five circular plots, with a $2 \mathrm{~m}$ radius, randomly dispersed within the emerging birch forest stand. These plots were separate from those used for demographic surveillance, although the general physiognomy was virtually the same. Within each plot, the highest stem of each individual was cored close to the root collar. In some cases, tight stool of stems necessitated removal of the surface vegetation and soil layer in order to approximately pin-point the time of individual establishment (cf. Kullman 2015a). Despite this careful and laborious procedure, the exact germination date is likely to have been missed in many cases (cf. Kullman 2013, 2015b). The cores were taken to the laboratory and tree rings were counted under a stereo microscope.

Birch seed viability was assessed annually (1980-2015) on a random sample of birch catkins collected in a 50 x $50 \mathrm{~m}$ plot on Mt. Getryggen, $775 \mathrm{~m}$ a.s.l. Germination tests in the laboratory were carried out as described by Kullman (1984).

The ground flora of vascular plants in the entire large plot was thoroughly documented by random walk in mid-July 1980 and 2015.

\section{RESUlTS AND DisCUSSION}

This study provides an opportunity to follow how alpine tundra transforms into mountain birch forest. A formerly persistent snowfield has melted earlier in summer, which has shaped a new habitat for sustained birch tree emergence and persistence. Accordingly, a small birch forest stand has grown up, whereby the early 1980s not a single tree existed, excluded by an extended period of snow cover. As a perspective to the present study, it may be pertinent to consider that initially treeless and snow accumulating swales, similar to the one supporting the emerging tree population, harboured birch trees until about 3500 to 3000 cal. yr BP (Kullman 1994, 2003). Subsequently, birch vegetation declined as a consequence of the general neoglacial cooling and associated vegetation and biodiversity regression (cf. Karlén 1976; Caseldine \& Matthews 1987; Eronen et al. 1999; Bergman et al. 2005; Paus 2010; Kullman 2013). Short climatic reversals to more congenial and tree supporting conditions may have occurred around 1900 and 1000 cal. yr BP (Kullman 2013, 2015b).

As evident from the age structure (Fig. 6), the considered progression of birch vegetation has continuity back to the second decade of the 20th century. For the following six decades, prevailing birches staggered as low-growing shrubs. The first tree-sized specimens were recorded in 2006. Thereafter, the stems heights and stand density have increased rapidly and progressively and virtually without any perceivable stem mortality (Table 1), as evidenced also by repeat photography (Figs 812).

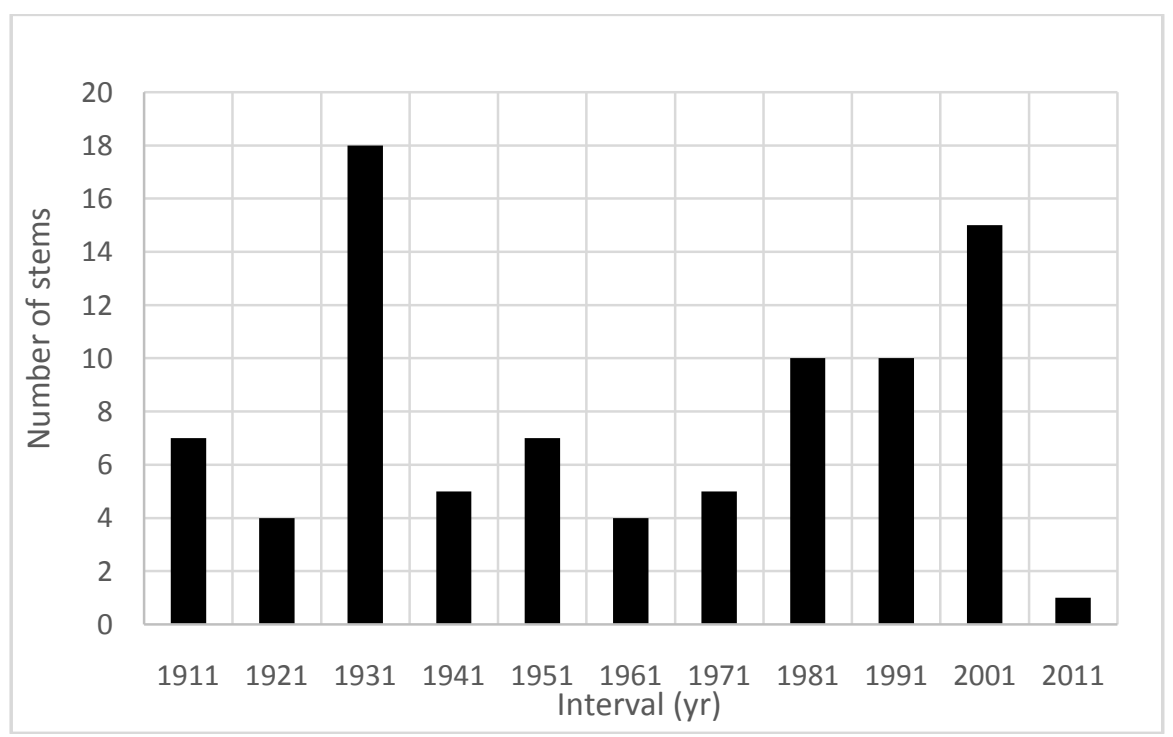

Fig6. Age structure of the birch population, expressed as the number of stems initiated during specific 10-yr intervals, 1911-1920, 1921-1930, etc. 
Leif Kullman

Table1. Stem-heights within five permanent plots, assessed at four occasions during the period 1980 to 2015.

\begin{tabular}{|c|c|c|c|}
\hline Year & Stem height $(\mathrm{m})$ & Max. height $(\mathrm{m})$ & Number of stems \\
\hline 1980 & $0.12 \pm 0.03$ & 0.35 & 45 \\
\hline 2006 & $0.75 \pm 0.53$ & 2.42 & 79 \\
\hline 2012 & $1.37 \pm 0.63$ & 3.55 & 87 \\
\hline 2015 & $1.69 \pm 0.74$ & 3.95 & 94 \\
\hline
\end{tabular}

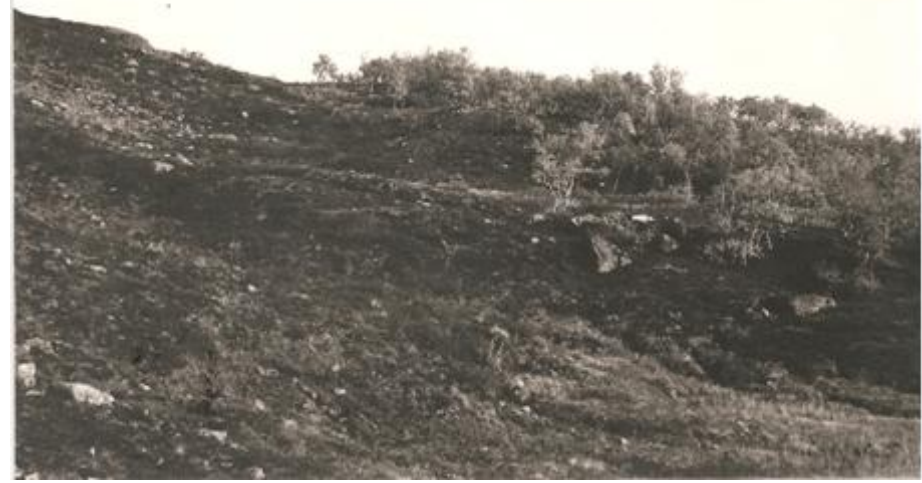

Fig7. The study site as it appeared when the study was initiated. A dense population of tiny birches (not seen here) had recently emerged in the trough between the slope to the left and the forest to the right. Photo: 198009-07.

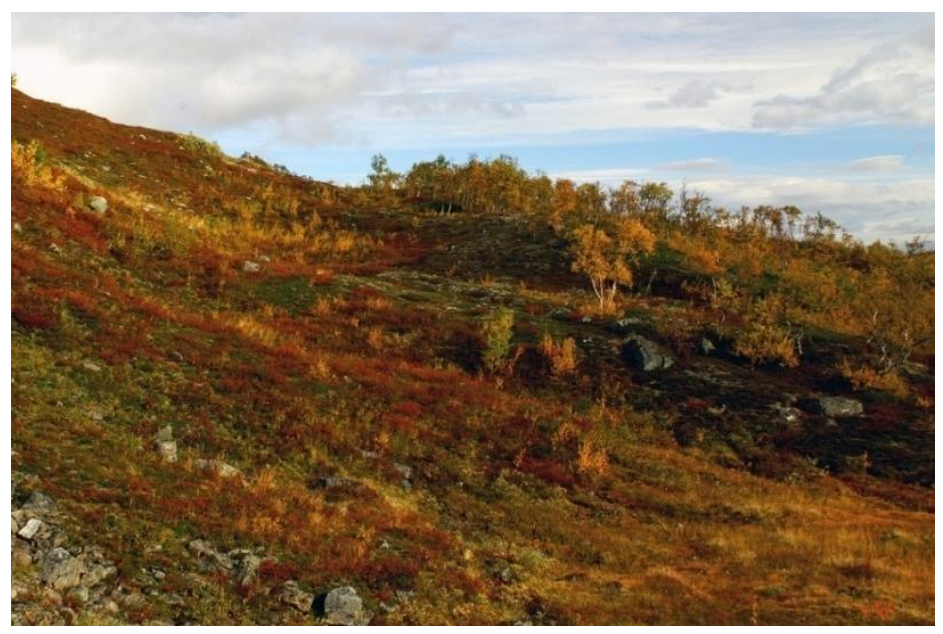

Fig8. The study site as it appeared by the autumn 2006. Expanding birch shrub vegetation characterizes the deeper parts of the terrain and the lower slopes to the left. Photo: 2006-09-25.

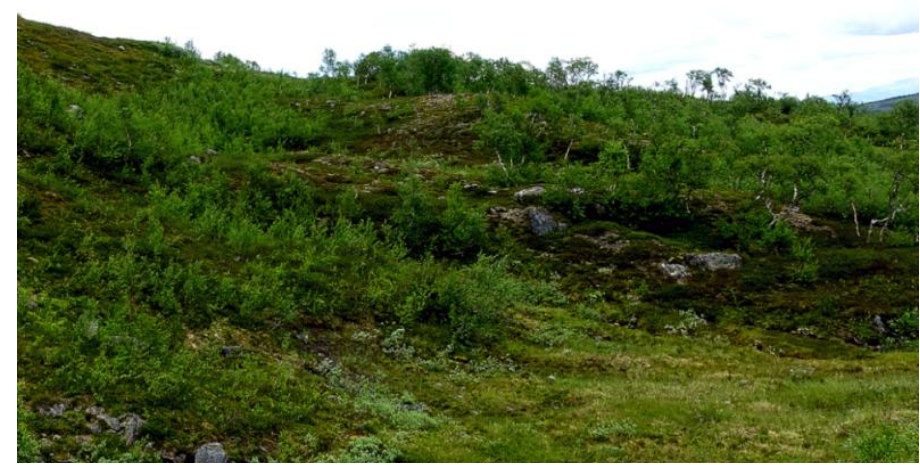

Fig9. By 2015, a dense and young birch forest stand has developed at the study site and the size of the previously treeless ground has diminished. Photo: 2015-07-28. 
Climate Change and Primary Birch Forest (Betula pubescens ssp. czerepanovii) Succession in the Treeline Ecotone of the Swedish Scandes

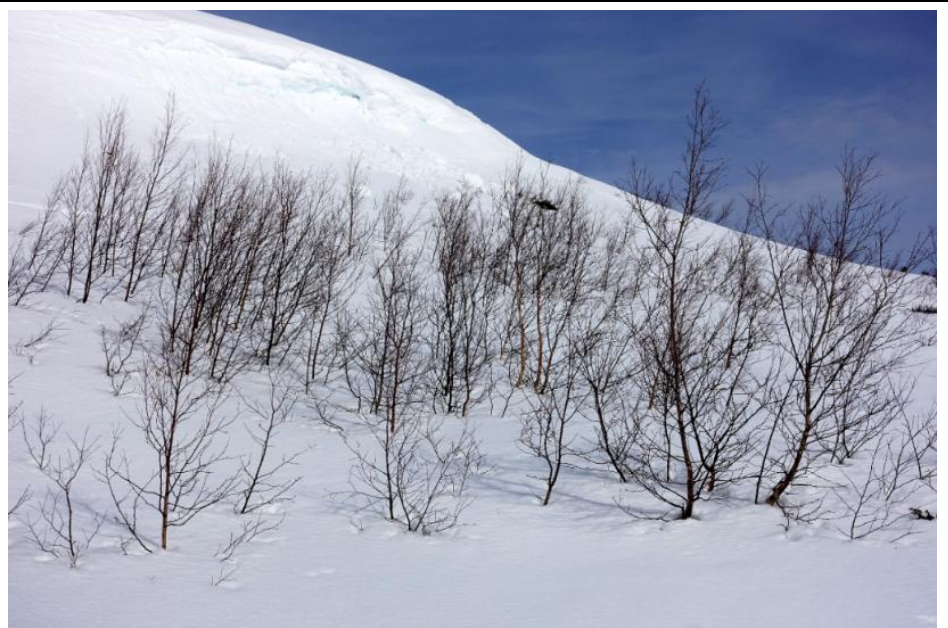

Fig10. Close-up structural view of the southern fringe of the new and rapidly growing forest stand. The highest birches have reached a size of about $4 \mathrm{~m}$. Photo: 2016-05-02.

The initiation of new stems (Fig. 6) bears a significant and positive relationship with summer temperature optima. Germinability and emergence of new stems peaked during the warmest decades of the past 100 years (Figs. 11 and 12), indicative of a possible link and mechanism between forest progression and temperature rise.

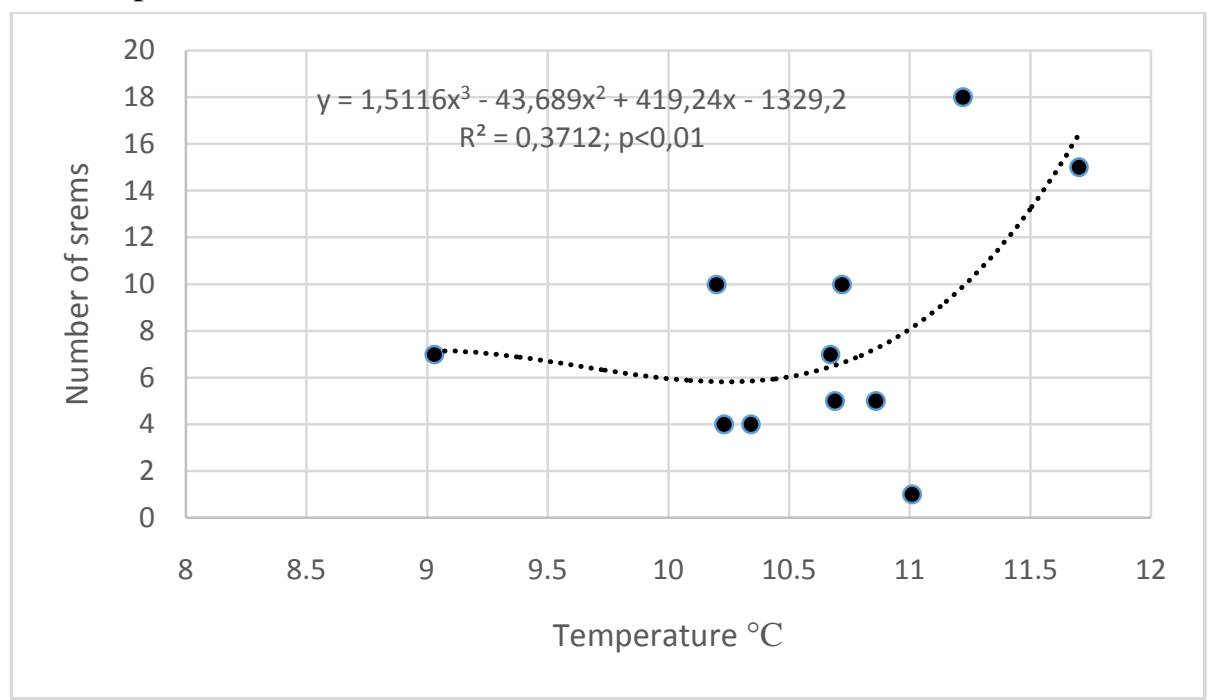

Fig11. Relationship between number of stems during specific 10-yr intervals and corresponding June-August mean air temperatures, recorded at the Storlien/Visjövalen meteorological station.

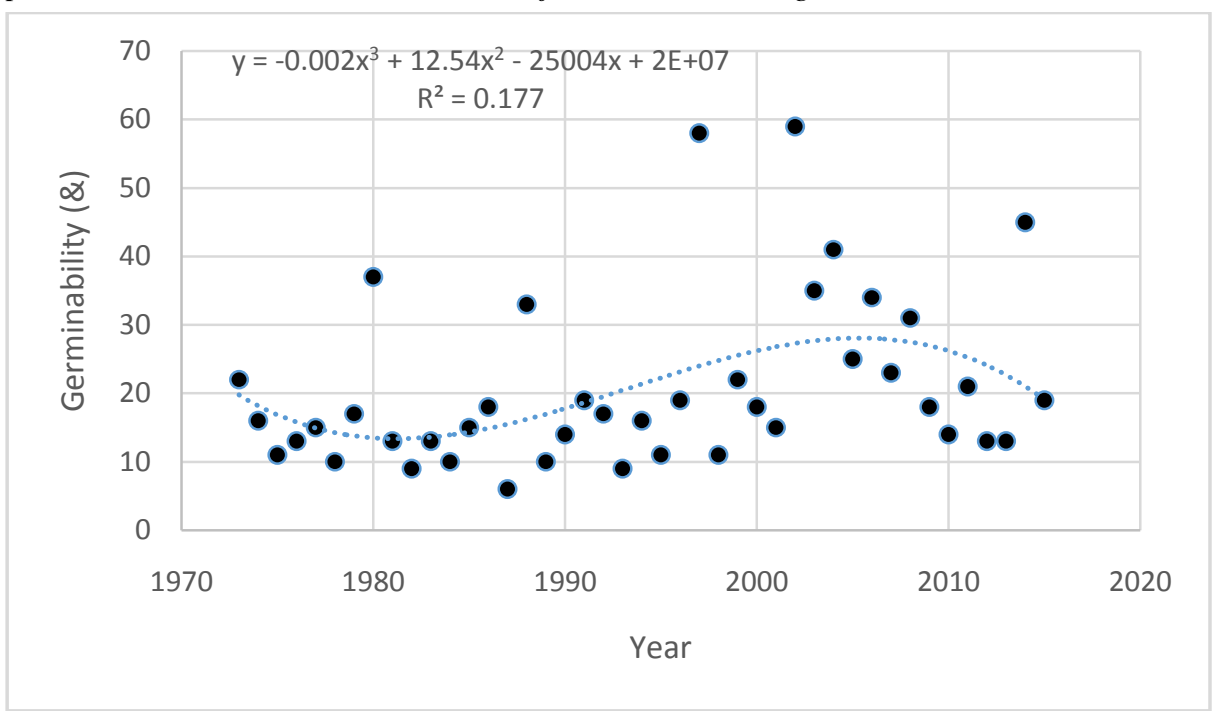

Fig12. Annual records of birch seed germinability, gathered in the upper subalpine birch forest of Mt. Getryggen, $800 \mathrm{~m}$ a.s.l., fairly close to the study site. 
Presumably, delayed growth progression until after the 1980s, may relate to constraints imposed by the large and late-lying snow bank covering much of the site. Analogous lags, i.e. initial slow response, appear as a recurrent phenomenon when trees invade treeless tundra (e.g. Chapin \& Starfield 1997; Esper \& Schweingruber 2004). This circumstance adds to mounting evidence that, relative to the tree line (as defined here), the elusive forest line may be out of equilibrium with prevailing climate and a poor indicator of ongoing climate-driven ecological change in the mountains (Körner 1999; Moen \& Lyngstad 2003; Kullman 2010; Rannow 2013). In general, disequilibrium conditions of this kind appear as a common aspect of plant cover performance in cold-marginal situations, which complicates correlation trials with ambient environmental variability (Zackrisson et al. 1995; Hiller et al. 2001; Paus 2013; Hofgaard et al. 2013; Normand et al. 2013).

As a postulated response in general (e.g. Aerts et al. 2006), the surge of birch cover progression may signal a shift towards more frequent sexual regeneration, when temperature has recently reached a certain, relatively high level (cf. Öberg \& Kullman 2012). This is quite a new situation, since during the past 30 years, regeneration in the upper subalpine belt has turned to become increasingly seedbased, contrasting with previous dominating vegetative birch regeneration in the tree line ecotone (Kullman 1979; Öberg \& Kullman 2012). This dichotomy has important bearing on projective tree cover models, since these need not to be entirely based on the existence of a bank of old-growth krummholz specimens above the tree line, ready to shift to tree-mode. Consequently, seed bed conditions need to be considered more thoroughly in connection with ongoing birch treeline dynamics.

Notably, coniferous Pinus sylvestris has recently become established as scattered individuals in the birch stand (Fig. 13). In addition, trials with exotic coniferous tree species, e.g. Picea engelmannii and Larix sibirica, have been quite successful in adjacent sparse birch forest. Thus it appears that mixed birch-pine forest may evolve at this site in a hypothetical warmer future, given that some self-thinning of the birch population occurs in the future (cf. Kullman in press).

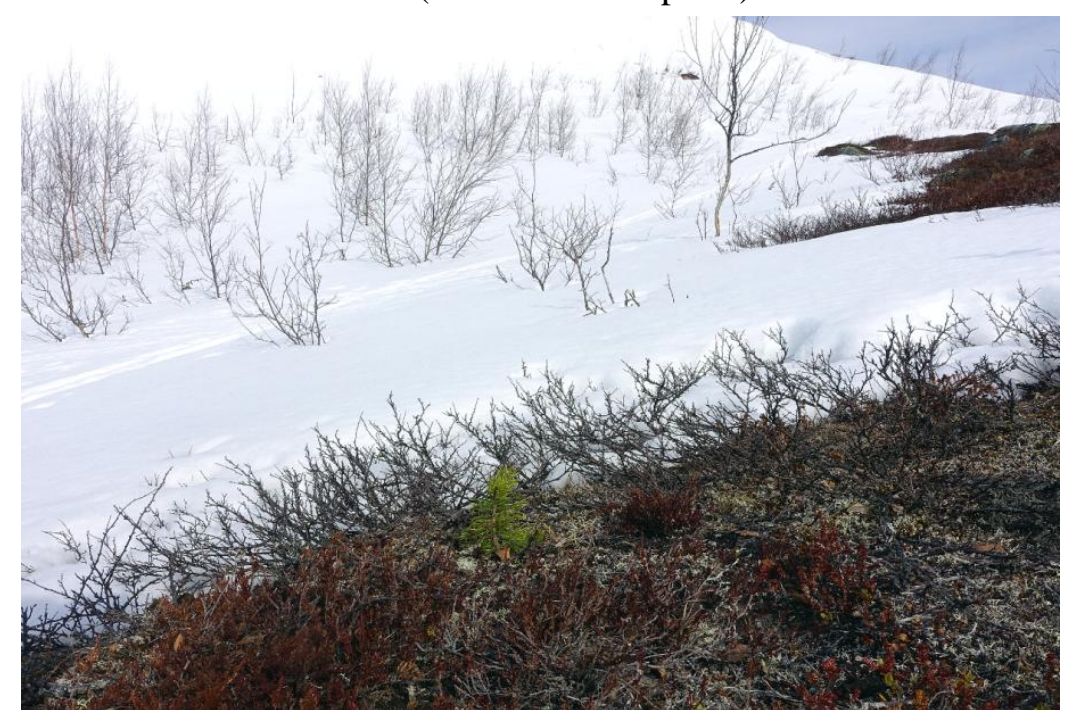

Fig13. Young pine sapling, established at the fringe of the emerging birch forest stand. Photo: 2016-05-02.

In parallel to tree progression, the ground flora has changed fundamentally between 1980 and 2015 in a way that is consistent with alpine demise and forest progression (Table 2). Several genuine alpine plants species have disappeared from the site with emerging birch forest, e.g. Alchemilla alpina, Oxyria digyna, Cassiope hypnoides, Diapensia lapponica, Ranunculus glacialis, Salix herbacea, Silene acaulis. In addition previous predominant swards of Nardus stricta have been replaced by Empetrum hermaphroditun and Betula nana. A few more or less typical boreal montane plants" have been added to the flora, e.g. Cornus suecica, Calluna vulgaris, Geranium sylvaticum, Juniperus communis, Melampyrum sylvaticum, Pinus sylvestris, Solidago virgaurea. Analogous results were obtained in the northernmost Swedish Scandes (Sundqvist et al. 2008).

Notably, the course of primary vegetation succession outlined in this study, i.e. the emergence of a localized mountain birch forest stand in the wake of receding snow and ice, may represent a modern analogue of the first Holocene birch forests about $9500 \mathrm{cal}$. yr BP. This contention draws on large numbers of birch megafossils being currently exposed at the fringe of alpine glaciers and snow fields in the high mountains (Öberg \& Kullman 2011, Kullman \& Öberg 2013, 2015). 
Climate Change and Primary Birch Forest (Betula pubescens ssp. czerepanovii) Succession in the Treeline Ecotone of the Swedish Scandes

Table2. List of vascular plant species recorded in the study area 1989 and 2015, respectively.

\begin{tabular}{|c|c|c|}
\hline Species & 1980 & 2015 \\
\hline Alchemilla alpina & $\mathrm{X}$ & \\
\hline Betula pubescens ssp.czerepanovii & $\mathrm{X}$ & $\mathrm{X}$ \\
\hline Betula nana & $\mathrm{X}$ & $\mathrm{X}$ \\
\hline Calluna vulgaris & & $\mathrm{X}$ \\
\hline Carex bigelowii & $\mathrm{X}$ & \\
\hline Carex lachenalii & $\mathrm{X}$ & \\
\hline Cassiope hypnoides & $\mathrm{X}$ & \\
\hline Cornus suecica & & $\mathrm{X}$ \\
\hline Deschampsia flexuosa & $\mathrm{X}$ & $\mathrm{X}$ \\
\hline Diapensia lapponica & $\mathrm{X}$ & \\
\hline Diphasiastrum alpinum & $\mathrm{X}$ & \\
\hline Empetrum hermaphroditum & $\mathrm{X}$ & $\mathrm{X}$ \\
\hline Epilobium angustifolium & & $\mathrm{X}$ \\
\hline Euphrasia frigida & $\mathrm{X}$ & $\mathrm{X}$ \\
\hline Gnaphlium supinum & $\mathrm{X}$ & \\
\hline Huperzia selago & $\mathrm{X}$ & \\
\hline Geranium sylvaticum & & $\mathrm{X}$ \\
\hline Gnaphlium supinum & $\mathrm{X}$ & \\
\hline Juncus trifidus & $\mathrm{X}$ & \\
\hline Juniperus communis & & $\mathrm{X}$ \\
\hline Loiseleuria procumbens & $\mathrm{X}$ & $\mathrm{X}$ \\
\hline Melampyrum pratense & & $\mathrm{X}$ \\
\hline Nardus stricta & $\mathrm{X}$ & \\
\hline Oxyria digyna & $\mathrm{X}$ & \\
\hline Phyllodoce caerulea & $\mathrm{X}$ & $\mathrm{X}$ \\
\hline Pinguicula vulgaris & $\mathrm{X}$ & \\
\hline Pinus sylvestris & & $\mathrm{X}$ \\
\hline Poa alpina & $\mathrm{X}$ & \\
\hline Ranunculus acris & & $\mathrm{X}$ \\
\hline Ranunculus glacialis & $\mathrm{X}$ & \\
\hline Salix herbacea & $\mathrm{X}$ & \\
\hline Salix phylicifolia & & $\mathrm{X}$ \\
\hline Salix reticulata & $\mathrm{X}$ & \\
\hline Saxifraga stellaris & $\mathrm{X}$ & \\
\hline Sibbaldia procumbens & $\mathrm{X}$ & \\
\hline Silene acaulis & $\mathrm{X}$ & \\
\hline Solidago virgaurea & & $\mathrm{X}$ \\
\hline Tofieldia pusilla & $\mathrm{X}$ & \\
\hline Trientalis europaea & & $\mathrm{X}$ \\
\hline Vaccinium myrtillus & $\mathrm{X}$ & $\mathrm{X}$ \\
\hline Vaccinium uliginosum & $\mathrm{X}$ & $\mathrm{X}$ \\
\hline Vaccinium vitis-idaea & & $\mathrm{X}$ \\
\hline
\end{tabular}

A minor case study, focusing on a vanishing subalpine "snow glade", about 5 kilometers to the north of the present site and deeper below the treeline, has yielded virtually the same results as in the present case (Kullman 2007b). This spatial reiteration of recent processes, affecting ground and tree layers, supports an interpretation in terms of climate change, mediated by snow-phenology (cf. Kullman 1979, 2014c), which concurs with general comprehension of mechanisms behind alpine plant cover dynamics (Gjærevoll 1956).

\section{ACKNOWLEDGEMENTS}

This study was defrayed by the Swedish Research Council for Environment, Agricultural Sciences and Spatial Planning (FORMAS). Dr. Lisa Öberg is thanked for field assistance and constructive comments on an early draft of the paper. 


\section{REFERENCES}

Aas, B. 1969. Climatically raised birch lines in southeastern Norway 1918-1968. Norsk Geografisk Tidsskrift 23, 119-130.

Aerts, R., Cornelissen, J.H.C. \& Dorrepal, E. 2006. Plant performance in a warmer world: general responses of plants from cold northern biomes and the importance of winter and spring events. Plant Ecology 182, 65-77.

Bergman, J., Hammarlund, D., Hannon, G., Barnekow, L. \& Wohlfarth, B. 2005. Deglacial vegetation succession and Holocene tree-limit dynamics in the Scandes Mountains, west-central Sweden: stratigraphic data compared to megafossil evidence. Review of Palaeobotany and Palynology 134, 129-151.

Boer, M.M., Koster, E.A. \& Lundberg, H. 1990. Greenhouse impact in Fennoscandia - preliminary findings of a European workshop on the effects of climate change. Ambio 19, 2-10-

Caseldine, C.J. \& Matthews, J. A. 1987. Podzol development, vegetation change and glacier variations at Haugabreen, southern Norway. Boreas 16, 215-230.

Chapin, F.S. \& Starfield, A.M. 1997. Time lags and novel ecosystems in response to transient climatic change in arctic Alaska. Climate Change 35, 449-462.

Danby, R.K. \& Hik., D.S. 2007. Evidence of recent treeline dynamics in southwest Yukon from aerial photographs. Arctic 60, 411-420.

Devi, N., Hagedorn, F., Moiseev, P., Bugmann, H., Shiyatov, S., Mazepa, V. \& Rigling, A. 2008. Expanding forests and changing growth forms of Siberian larch at the Polar Urals treeline during the 20th century. Global Change Biology 14, 1581-1591.

Elliott, G.P. \& Kipfmueller, K.I. 2010. Multi-scale influences of slope aspect and spatial pattern on ecotonal dynamics at upper treeline in the Southern Rocky Mountains, U.S.A. Arctic, Antarctic, and Alpine Research 42, 42-56.

Eronen, M., Lindholm, M., Saastamoinen, S. \& Zetterberg, P. 1999. Variable Holocene climate, treeline dynamics and changes in natural environments in northern Finnish Lapland. Chemosphere: Global Change Science 1, 377-387

Esper, J. \& Schweingruber, F.H. 2004. Large-scale treeline changes recorded in Siberia. Geophysical Research Letters 31, 1-5.

Ettinger, A.K. \& HilleRisLambers, J. 2013. Climate isn't everything: competitive interactions and variability of life stage will also affect range shifts in a warming world. American Journal of Botany 100, 1344-1355.

Gjærevoll, O. 1956. The plant communities of the Scandinavian alpine snow-beds. Det Konglige Norske Videnskabers Selskabs Skrifter 1956(1), 1-405.

Harsch, M.A., Hulme, P.E., McGlone, M.S. \& Duncan, R.P. 2009. Are treelines advancing? A global meta-analysis of treeline response to climate warming. Ecology Letters 12, 1040-1049.

Hiller, A., Boettger, T. \& Kremenetski, K. 2001. Mediaeval climate warming recorded by radiocarbon dated alpine tree-line shift on the Kola Peninsula, Russia. The Holocene 11, 491-497.

Hofgaard, A., Dalen, L. \& Hytteborn, H. 2009. Tree recruitment above the treeline and potential for climate-driven treeline change. Journal of Vegetation Science 20, 1133-1144.

Hofgaard, A., Tømmervik, H., Rees, G. \& Hanssen, F. 2013. Latitudinal forest advance in northernmost Norway since the early 20th century. Journal of Biogeography 40, 938-949.

Hustich, I. 1979. Ecological concepts and biogeographical zonation in the North: the need for a generally accepted terminology. Holarctic Ecology 2, 208-217.

Johnson, E.A., Miyaniski, K. \& Kleb, H. 1994. The hazards of interpreting static age structures as shown by stand reconstructions in a Pinus contorta-Picea engelmannii forest, Journal of Ecology $82,921-930$.

Kellomäki, S., Väisänen, H. \& Kolström, T. 1997. Model computations on the effects of elevating temperature and atmispheric $\mathrm{CO}_{2}$ on the regeneration of Scots pine at the timberline in Finland. Climatic Change 37, 683-708.

Kapralov, D.S., Shiyatov, S.G., Moiseev, P.A. \& Fomin, V.V. 2006. Changes in composition, structure, and altitudinal distribution of low forests at the upper limit of their growth in the Northern Ural Mountains. Russian Journal of Ecology. 37, 367-372. 
Climate Change and Primary Birch Forest (Betula pubescens ssp. czerepanovii) Succession in the Treeline Ecotone of the Swedish Scandes

Karlén, W. 1976. Lacustrine sediments and tree-limit variations as indicators of Holocene climatic fluctuations in Lappland; northern Sweden. Geografiska Annaler 58A, 1-34.

Klasner, F.L. \& Fagre, D.B. 2002. A half century of change in alpine treeline patterns of Glacier National Park. Montana, U.S.A. Arctic, Antarctic, and Alpine Research 34, 49-56.

Körner, C. 1999. Alpine Plant Life. Functional Plant Ecology and High Mountain Ecosystems. Springer, Berlin. 238 pp.

Kullman, L. 1979. Change and stability in the altitude of the birch tree-limit in the southern Swedish Scandes 1915-1975. Acta Phytogeographica Suecica 65, 1-121.

Kullman, L. 1984. Germinability of mountain birch (Betula pubescens ssp. tortuosa) along two altitudinal transects downslope from the tree-limit in Sweden. Reports from the Kevo Subarctic Research Station 19, 11-18.

Kullman, L. 1991. Dynamics of altitudinal tree-limits in Sweden: a review. Norsk Geografisk Tidsskrift 44, 103-116.

Kullman, L. 1994. The Holocene history of a subalpine birch forest enclave: subfossil evidence from Central Sweden. Géographie Physique et Quaternaire 48, 151-156.

Kullman, L. 1995. Holocene tree-limit and climate history from the Scandes Mountains, Sweden. Ecology 76, 2490-2502.

Kullman, L. 2003. Recent reversal of Neoglacial climate cooling trend in the Swedish Scandes as evidenced by mountain birch tree-limit rise. Global and Planetary Change 36, 77-88.

Kullman, L. 2005. Pine (Pinus sylvestris) treeline dynamics during the past millennium - a population study in west-central Sweden. Annales Botanici Fennici 42, 95-106.

Kullman, L. 2007a. Long-term geobotanical observations of climate change impacts in the Scandes of West-Central Sweden. Nordic Journal of Botany 24, 445-467.

Kullman, L. 2007b. Modern climate change and shifting ecological states of the subalpine /alpine landscape in the Swedish Scandes. GeoÖko 28, 187-221.

Kullman, L. 2010. One century of treeline change and stability - experiences from the Swedish Scandes. Landscape Online 17, 1-31.

Kullman, L. 2013. Ecological tree line history and palaeoclimate - review of megafossil evidence from the Swedish Scandes. Boreas 42, 555-567.

Kullman, L. 2014a. Treeline (Pinus sylvestris) landscape evolution in the Swedish Scandes - a 40year demographic effort viewed in a broader temporal context. Norwegian Journal of Geography $68,155-167$.

Kullman, L. 2014b. Trädgränsens förändring 1974 till 2014. Fotoserie från fjället Östra Barfredhågnai norra Dalarna. Rapport 2014:09. Länsstyrelsen Dalarnas län.

Kullman, L. 2014c. Recent cooling and dynamic responses of alpine summit floras in the southern Swedish Scandes. Nordic Journal of Botany 32, 369-376.

Kullman, L. 2015a. Recent and past trees and climates at the Arctic/Alpine margin in Swedish Lapland: an Abisko case study review. Journal of Biodiversity Management \& Forestry 15, 4:4. doi.org/10.4172/2327-4417.1000150.

Kullman, L. 2015b. Higher-than-present Medieval pine (Pinus sylvestris) treeline along the Swedish Scandes. Landscape Online 42, 1-14.

Kullman, 2015c. Norway spruce (Picea abies (L.) Karst.) treeline ecotone performance since the mid1970s in the Swedish Scandes - evidence of stability and minor change from repeat surveys and photography. GeoÖko 36, 23-53.

Kullman, L. in press with 2016 a. Fjällen, klimatet och människan. (Mountains, climate and Man natural history at the interface between two ice ages. Svensk Botanisk Tidskrift 100, 120-272.

Kullman, L. in press Pine (Pinus sylvestris L.) penetration towards the head of the Handölan Valley: recent reversal of long-terms retrogressional trend - contrasting responses to climate change of tree- and forest line. International Journal of Environmental \& Agriculture Research 2 (5).

Kullman, L. \& Öberg, L. 2009. Post-Little Ice Age tree line rise and climate warming in the Swedish Scandes: a landscape ecological perspective. Journal of Ecology 97, 415-429. 
Kullman, L. \& Öberg, L. 2013. Melting glaciers and ice patches in Swedish Lapland provide new insights into the the Holocene arboreal history. Geo-Öko 33, 121-146

Kullman, L. \& Öberg, L. 2015. New aspects of high-mountain palaeobiogeography: a synthesis of data from forefields of receding glaciers and ice patches in the Tärna and Kebnekaise Mountains, Swedish Lapland. Arctic 68, 141-152.

Lundqvist, J. 2012. När inlandsisen lämnade Jämtlandsfjällen. Geologiskt Forum 19 (73), 10-17.

Moen, A. \& Lyngstad, A. 2003. Botaniske verneverdier i Sylan. Norges Teknisk-Naturvitenskapelig Universitet Vitenskapsmuseet Rapport botanisk serie 2003-5, 1-39.

Moen, J., Aune, K., Edenius, L. \& Angerbjörn, A. 2004. Potential effects of climate change on treeline position in the Swedish mountains. Ecology \& Society 9, 1-10.

Mossberg, B. \& Stenberg, L. 2003. Den Nya Nordiska Floran. Wahlström \& Widstrand, Stockholm.

Normand, S., Randin, C., Ohlemüller, R. \& 12 others 2013. A greener Greenland? Climatic potential and long-term constraints on future expansions of trees and shrubs. Philosophical Transactions of the Royal Society B 368, 20120479 (2013).

Öberg, L. \& Kullman, L. 2011. Recent glacier recession - a new source of postglacial treeline and climate history in the Swedish Scandes. Arctic 64, 136-142.

Öberg, L. \& Kullman, L. 2012. Contrasting short-term performance of mountain birch (Betula pubescens ssp. czerepanovii) along a latitudinal continentality-maritimity gradient in the southern Swedish Scandes. Fennia 190, 19-40.

Oldfield, F. 2005. Environmental Change. Key Issues and Alternative Perspectives. Cambridge University Press, Cambridge.

Olofsson, J., Oksanen, L., Callaghan, T., Hulme, P.E., Oksanen, T. \& Suominen, O. 2009. Herbivores inhibit climate-driven shrub expansion in the tundra. Global Change Biology 15, 2681-2693.

Paus, A. 2010. Vegetation and environment of the Rødalen alpine area, central Norway, with emphasis on the early Holocene. Vegetation History and Archaeobotany 19, 29-51.

Rannow, S. 2013. Do shifting forest limits in south-west Norway keep up with climate change? Scandinavian Journal of Forest Research 28, 574-580.

Rapp, A. 1996. Photo documentation of landscape change in northern Swedish Mountains. Ecological Bulletins 45, 170-179.

Shiyatov, S.G. 2003. Rates of change in the upper treeline ecotone in the Polar Ural Mountains. Pages News 11, 6-8.

SOU. 2006. Samernas sedvanemarker. Statens Offentliga Utredningar 2006 (14), 1-194.

Sing, C.P., Panigrahy, S., Thapliyal, A., Kimothi, M.M., Soni, P. \& Parihar, J.S. 2012. Monitoring the alpine treeline shift in parts of the Indian Himalayas using remote sensing. Current Science 1002, 559-562.

Sundqvist, M.K., Björk, R.G. \& Molau, U. 2008. Establishment of boreal forest species in alpine dwarf-shrub heath in subarctic Sweden. Plant Ecology \& Diversity 1, 67-75.

Van Bogaert, R., Haneca, K., Hoogesteger, J., Jonasson, C., De Dapper, M. \& Callaghan, T. 2011. A century of tree line changes in sub-Arctic Sweden shows local and regional variability and only minor influence of 20th century climate warming. Journal of Biogeography 38, 907-921.

Villalba, R. \& Veblen, T.T. 1997. Regional patterns of tree population age structures in northern Patagonia: Climate and disturbance influences. Journal of Ecology 85, 113-124.

Webb, R.H., Boyer, D.E. \& Turner, R.M. 2010. Repeat photography: methods and applications in the natural sciences. Island Press, Washington, D.C.

Zackrisson, O., Nilsson, M.-C., Steijlen, I. \& Hörnberg, G. 1995. Regeneration pulses and climatevegetation interactions in nonpyrogenic boreal Scots pine stands. Journal of Ecology 83, 469483.

Zier, J.L. \& Baker, W.L. 2006. A century of vegetation change in the San Juan Mountains, Colorado: An analysis using repeat photography. Forest Ecology and Management 228, 251-262. 